\title{
Analysis of the Effectiveness of a Problem-based Digital Textbook
}

\author{
Chan-Seok Park ${ }^{1}$, Mihye Kim ${ }^{2}$, Kwan-Hee Yoo ${ }^{1, *}$ \\ ${ }^{1}$ Department of Computer Education, Chungbuk National University, \\ 410 Seongbongro Heungdukgu Cheongju Chungbuk, Korea \\ dayfly96@naver.com,khyoo@chungbuk.ac.kr \\ ${ }^{2}$ Department of Computer Science Education, Catholic University of Daegu, Korea \\ mihyekim@cu.ac.kr
}

\begin{abstract}
The successful use of digital textbooks (DTs) in schools requires the development of various teaching and learning methods that are appropriate for DTs. However, recent DT studies have focused mainly on the implementation of DT features and formats. The objective of this study was to investigate a problem-based learning instructional model appropriate to DTs and to present the experimental results using the problem-based DT to demonstrate its educational effectiveness. Two learning-achievements tests were conducted to analyze the learning experience and effectiveness of the problem-based DT after it had been used in a high school for a certain period. The experimental results indicated that the students who used the DT, especially lower-level students, exhibited improved problem-solving ability and demonstrated a better practical understanding of the subject than students who used printed textbooks.
\end{abstract}

Keywords: Digital textbook, Problem-based digital textbook, Problem-based learning, Effectiveness of problem-based digital textbook

\section{INTRODUCTION}

Digital textbooks (DTs) could help change the future of education through the use of state-of-the-art information technology (IT) services including multimedia, Web 2.0, and cloud computing. DTs also present new possibilities for innovation in educational content, teaching and learning methods, and evaluation to empower students and create a smart educational environment. In such DT environments, students can learn continuously via any device connected through a wired or wireless network without time and space limitations, while saving their DTs and learning data online [1]. In 2011, the South Korean government announced its Smart Educational Strategy Action Plan to shift from the current printed textbooks (PTs) used in elementary and secondary schools to DTs by 2015, with the aim of creating a cloud-based educational service environment for future schools [2]. In line with this plan, the Korean government developed prototype DTs for the five major subjects taught in elementary schools. These DTs are now being tested in 132 schools before eventual distribution to all elementary and secondary schools across the country by 2015 [2], [3], [4]. Recent DT research has focused mainly on the implementation of DT features and formats as replacements for PTs, taking advantage of digital media.

\footnotetext{
* Corresponding author, Email: khyoo@chungbuk.ac.kr Manuscript received Mar. 14, 2012; revised May 15, 2012; accepted May 17, 2012
}

However, successful use of DTs in modern schools requires the development of appropriate innovative and creative teaching and learning methodologies [2].

For this reason, we defined a problem-based learning (PBL) instructional model suitable for DTs, and developed a DT that supports PBL based on this model for teaching general computing in commercial high schools in South Korea [5], [6]. Our objective was to investigate more diversified learning methods appropriate to DTs to enhance student learning and achievement in self-directed and differentiated learning environments. We used our proposed system experimentally in a high-school class and herein present the results of its use to demonstrate its educational effectiveness.

The remainder of this paper is organized as follows. Section 2 provides an overview of the PBL DT, and Section 3 presents the prototype DT used in a high-school computing class. Section 4 presents the experimental results from two learningachievement tests (LATs) carried out after using our proposed system. Section 5 concludes the paper with a summary of the experimental results and directions for future research.

\section{THE PROPOSED PBL DT}

PBL is a student-centered instructional method that emphasizes learning instead of teaching [7], [8]. It aims to help students to develop flexible knowledge, problem-solving skills, and self-directed learning skills in the direction of experiential 
learning [9]. In this approach, students first receive a practical problem and then learn while solving it using self-directed and cooperative approaches. Figure 1 illustrates the overall PBL concept.

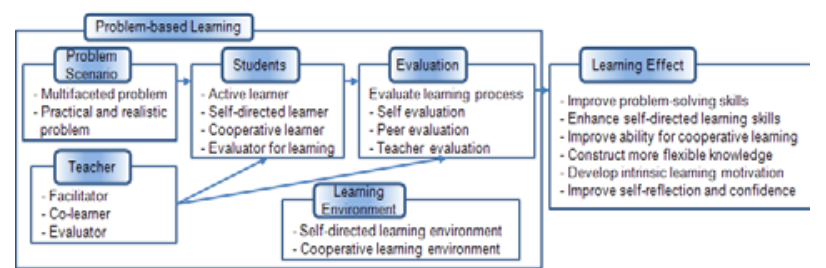

Fig. 1. The conceptual model of integral imaging

Following the basic PBL concepts and referring to the PBL learning cycles presented by Barrow [10] and Hmelo-Silver [9], we defined a six-phase instructional PBL model for DTs in a previous paper [5]. Figure 2 shows the PBL instructional model for DTs.

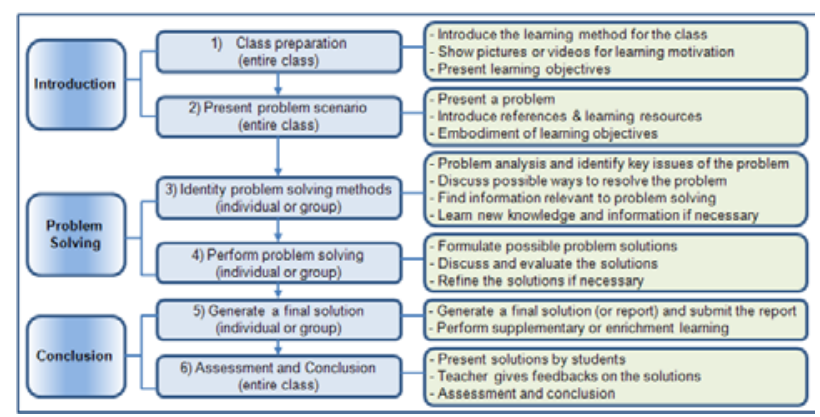

Fig. 2. Proposed PBL instructional model for DTs

Focusing on the features that can support the PBL process with the basic functions of traditional DTs, we defined the features of the proposed PBL DT by dividing them into three categories as shown in Table 1.

Table 1. Features of the proposed PBL DT

\begin{tabular}{|c|c|l|}
\hline Feature & Details & \multicolumn{1}{|c|}{ Explanation } \\
\hline \hline $\begin{array}{c}\text { Leasic } \\
\text { Feature }\end{array}$ & $\begin{array}{c}\text { Features } \\
\text { as } \\
\text { a textbook }\end{array}$ & $\begin{array}{l}\text {-Provide the functions of traditional PTs (e.g., } \\
\text { writing, memos and notes, underlining and } \\
\text { highlighting, bookmarks, page turning, } \\
\text { moving to a particular page by previous or } \\
\text { next buttons, page navigator, table of contents, } \\
\text { index) }\end{array}$ \\
\hline $\begin{array}{c}\text { Learning } \\
\text { Support } \\
\text { Feature }\end{array}$ & $\begin{array}{l}\text { Multimedia } \\
\text { Function }\end{array}$ & $\begin{array}{l}\text {-Provide various multimedia features and } \\
\text { objects (e.g., images, sounds, graphics, } \\
\text { animations, videos, virtual reality) }\end{array}$ \\
\cline { 2 - 4 } & References & $\begin{array}{l}\text {-Provide various outside learning resources } \\
\text { and materials }\end{array}$ \\
\cline { 2 - 4 } & Glossaries & $\begin{array}{l}\text {-Provide glossaries and dictionaries needed } \\
\text { for learning }\end{array}$ \\
\cline { 2 - 4 } & Search & $\begin{array}{l}\text {-Find information related to problem solving } \\
\text { Fithin the DT or in outside learning resources } \\
\text { hyperlinked to the DT }\end{array}$ \\
\cline { 2 - 5 } & Hyperlinks & $\begin{array}{l}\text {-Hyperlinks to a variety of learning materials } \\
\text { and resources to stimulate self-directed } \\
\text { learning and differentiated learning }\end{array}$ \\
\cline { 2 - 4 } & Interaction & $\begin{array}{l}\text {-Interactions between the teacher and } \\
\text { students, with the DT and communicate with } \\
\text { each other for problem solving (e.g., e-mail, }\end{array}$ \\
\cline { 2 - 4 } & s
\end{tabular}

\begin{tabular}{|c|c|c|}
\hline & & $\begin{array}{l}\text { bulletin board, chatting, specific websites, } \\
\text { blogs) }\end{array}$ \\
\hline \multirow[t]{3}{*}{$\begin{array}{l}\text { Learning } \\
\text { Management } \\
\text { Feature }\end{array}$} & $\begin{array}{l}\text { Assessment } \\
\text { Tools }\end{array}$ & $\begin{array}{l}\text {-Support internal and external assessment } \\
\text { tools for evaluating students' problem-solving } \\
\text { results and determining students' } \\
\text { understanding level for supplementary and } \\
\text { enrichment learning }\end{array}$ \\
\hline & $\begin{array}{c}\text { Learning } \\
\text { Management }\end{array}$ & \begin{tabular}{|l}
-Manage each student’s understanding level \\
-Manage e-portfolios
\end{tabular} \\
\hline & $\begin{array}{l}\text { Authoring } \\
\text { Tools }\end{array}$ & $\begin{array}{l}\text {-Create/edit/print problem content and } \\
\text { problem-solving results using authoring tools } \\
\text { (e.g., edit text, pictures, music, videos) }\end{array}$ \\
\hline
\end{tabular}

\section{USE OF THE PROPOSED PBL DT IN A GENERAL COMPUTING CLASS}

We developed a DT for a general computing course taught in commercial high schools to verify its educational effectiveness. The DT was designed to support PBL based on the instructional model shown in Figure 2.

In this instructional approach, teachers first introduce the learning method and organize learning groups if necessary. Then they start the class by showing a video or threedimensional moving graphics that are provided in the DT to motivate the students and introduce the learning objectives. Then they present a problem along with information about the learning materials and resources needed to solve the problem. Finally, they direct students to solve the problem individually or in groups; that is, the problem can be solved by individual learning or cooperative learning depending on the subject matter.

In the first stage, students analyze and identify key issues and facts relevant to the problem, and think about possible ways to solve it. Then they identify what they already know and what they need to know that is relevant to the problem at hand. They acquire the knowledge required to solve the problem by referring to various learning materials and resources supported by the DT through self-directed and/or cooperative learning. The students formulate possible solutions to the problem by applying the new knowledge they have acquired, and evaluate and refine their solutions if necessary. Then they generate their final solutions on the learning activity sheets in the DT using authoring tools that allow users to create and edit text, graphics, and audio. The final solutions are submitted and posted on a bulletin board in the DT for crossreferencing. After submitting the final reports, the students can engage in supplementary or enrichment learning depending on their level of understanding. In the final stage of the PBL instructional model, the students present their solutions in class and the teacher provides feedback.

Figure 3 shows examples of a motivational video about learning (left), a problem (middle), and a learning process associated with problem solving (right). 


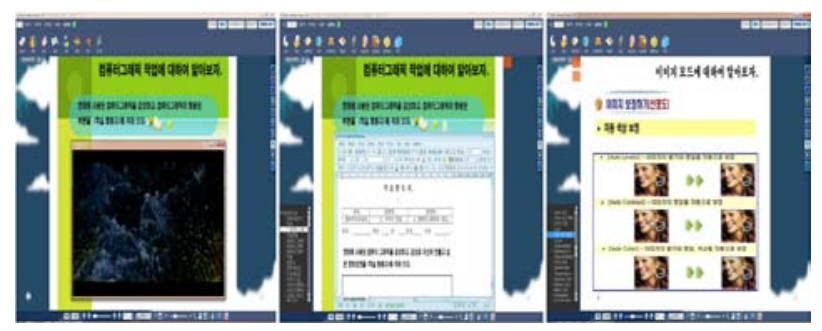

Fig. 3. Examples of a motivational video about learning (left), a problem (middle), and a learning process to acquire knowledge required to solve the problem (right)

\section{EXPERIMENTS}

\subsection{Experimental Design}

For the experiment, the PBL DT we implemented was used in actual classrooms at a commercial high school. We selected three classes of second-year high school students as the experimental group (i.e., classes that used the DT) and three other classes as the control group (i.e., classes that used a traditional PT) for a comparative study. Then, one teacher conducted the PBL lessons four times each in the experimental and control groups. To minimize the Hawthorne effect, we did not inform the students that they were participating in an experiment.

To verify the educational effectiveness of our proposed system, two LATs were administered after conducting the PBL lessons in each group. The first LAT was conducted with a theory-based exam, and the second was conducted with a problem-based exam; i.e., the students were given a practical problem to solve. To ensure the reliability of this assessment, three teachers scored the exam based on 15 evaluation criteria, and averaged their scores. We used the scores from the final exam conducted right before using the DT (i.e., pre-test) for a comparison of learning achievement. The comparison subjects were limited to 180 students by selecting 90 students from each treatment group who participated in all of the classes, learning activities, and surveys during the experiment. The LAT results were compared to the pre-test scores and classified into four performance groups based on score: 0 24.9\%, 25 49.9\%, 50 $74.9 \%$ and $75 \sim 100 \%$.

We also conducted a survey on user satisfaction (attention, relevance, confidence, and satisfaction), usability, and understanding about the DT using a 47-item questionnaire that is not included here due to space limitations.

\subsection{Experimental Results}

Table 2 shows the average scores of the two treatment groups for the pre-test. The mean score of the experimental group was 76.74 with a standard deviation (SD) of 17.08 , while that of the control group was 69.92 (SD = 14.83). The results of the independent $t$-test for homogeneity of variance between the two treatment groups indicated that no significant difference existed between the two groups ( $t=0.911, p=0.059, p>0.05$ )
Table 2. Average pre-test scores of the two treatment groups

\begin{tabular}{|c|c|c|c|}
\hline Treatment group & \begin{tabular}{|c|} 
Experimental \\
Group (DT)
\end{tabular} & $\begin{array}{c}\text { Control } \\
\text { Group (PT) }\end{array}$ & Total \\
\hline Performance group & \begin{tabular}{|c|}
$\begin{array}{c}\text { Average(SD) } \\
\text { Number }\end{array}$ \\
\end{tabular} & $\begin{array}{c}\text { Average(SD) } \\
\text { Number }\end{array}$ & $\begin{array}{c}\text { Average(SD) } \\
\text { Number }\end{array}$ \\
\hline $\begin{array}{l}\text { Group 1 } \\
(0 \sim 24.9 \%)\end{array}$ & $\begin{array}{c}45.28(7.67) \\
\mathrm{n}=23\end{array}$ & $\begin{array}{c}50.46(8.88) \\
n=23\end{array}$ & $\begin{array}{c}47.87(8.61) \\
n=46\end{array}$ \\
\hline $\begin{array}{c}\text { Group } 2 \\
(25 \sim 49.9 \%)\end{array}$ & $\begin{array}{c}61.93(4.59) \\
n=22\end{array}$ & $\begin{array}{c}65.70(2.46) \\
n=20\end{array}$ & $\begin{array}{c}63.73(4.15) \\
n=42\end{array}$ \\
\hline $\begin{array}{c}\text { Group } 3 \\
(50 \sim 74.9 \%)\end{array}$ & $\begin{array}{c}75.70(3.78) \\
n=23\end{array}$ & $\begin{array}{c}75.44(3.04) \\
n=25\end{array}$ & $\begin{array}{c}75.56(3.38) \\
n=48\end{array}$ \\
\hline $\begin{array}{c}\text { Group } 4 \\
(75 \sim 100 \%)\end{array}$ & $\begin{array}{c}88.73(4.49) \\
n=22\end{array}$ & $\begin{array}{c}87.81(5.48) \\
n=22\end{array}$ & $\begin{array}{c}88.27(4.97) \\
n=44\end{array}$ \\
\hline Total & $\begin{array}{c}67.74(17.08) \\
n=90\end{array}$ & $\begin{array}{c}\text { 69.92(14.83) } \\
\mathrm{n}=90\end{array}$ & $\begin{array}{c}\text { 68.83(15.99) } \\
n=180\end{array}$ \\
\hline
\end{tabular}

Table 3 shows the results of the first LAT. An analysis of variance (ANOVA) was performed to confirm whether significant differences existed between the experimental and control groups for learning achievement. There was no significant relation between the treatment and performance groups $(f=1.161, p>0.05)$ as can be seen in Table 4 . In addition, the results of the independent $t$-test revealed no statistically significant differences between the two treatment groups ( $t=0.487, p=0.627, p>0.05$ ), whereas some effect appeared in the performance groups ( $p=0.000, p<0.05)$. However, this had no direct relation with learning effectiveness because this was due to each student's own learning ability. These data indicate that the PBL DT did not impede the theoretical understanding of the subject, even if the DT was centered on problem sets.

Table 3. Mean percentile scores of the treatment and performance groups for the first LAT (theory-based exam)

\begin{tabular}{|c|c|c|c|}
\hline Treatment group & \begin{tabular}{|c|} 
Experimental \\
Group (DT)
\end{tabular} & $\begin{array}{c}\text { Control } \\
\text { Group (PT) }\end{array}$ & Total \\
\hline Performance group & $\begin{array}{c}\text { Average(SD) } \\
\text { Number }\end{array}$ & $\begin{array}{c}\text { Average(SD) } \\
\text { Number }\end{array}$ & $\begin{array}{c}\text { Average(SD) } \\
\text { Number }\end{array}$ \\
\hline $\begin{array}{c}\text { Group 1 } \\
(0 \sim 24.9 \%)\end{array}$ & $\begin{array}{c}55.22(10.39) \\
n=23\end{array}$ & $\begin{array}{c}55.65(10.80) \\
n=23\end{array}$ & $\begin{array}{c}55.43(10.48) \\
n=46\end{array}$ \\
\hline $\begin{array}{c}\text { Group } 2 \\
(25 \sim 49.9 \%)\end{array}$ & $\begin{array}{c}55.90(4.59) \\
n=22\end{array}$ & $\begin{array}{c}60.00(2.46) \\
n=20\end{array}$ & $\begin{array}{c}57.86(4.70) \\
n=42\end{array}$ \\
\hline $\begin{array}{c}\text { Group } 3 \\
(50 \sim 74.9 \%)\end{array}$ & $\begin{array}{c}72.17(5.18) \\
n=23\end{array}$ & $\begin{array}{c}70.80(2.77) \\
n=25\end{array}$ & $\begin{array}{c}71.46(4.12) \\
n=48\end{array}$ \\
\hline $\begin{array}{c}\text { Group } 4 \\
(75 \sim 100 \%)\end{array}$ & $\begin{array}{c}89.55(6.53) \\
n=22\end{array}$ & $\begin{array}{c}90.00(7.56) \\
n=22\end{array}$ & $\begin{array}{c}89.77(6.98) \\
n=44\end{array}$ \\
\hline Total & $\begin{array}{c}\text { 68.11(15.71) } \\
\mathrm{n}=90\end{array}$ & $\begin{array}{c}69.22(14.85) \\
n=90\end{array}$ & $\begin{array}{c}68.67(15.25) \\
n=180\end{array}$ \\
\hline
\end{tabular}

Table 4. Analysis of variance for the theory-based exam

\begin{tabular}{|c|r|r|r|r|c|}
\hline Variance & $\begin{array}{c}\text { Sum of } \\
\text { Squares }\end{array}$ & $\begin{array}{c}\text { Degree of } \\
\text { Freedom }\end{array}$ & $\begin{array}{c}\text { Mean } \\
\text { Squares }\end{array}$ & F & p-value \\
\hline \hline $\begin{array}{c}\text { Treatment } \\
\text { Groups (T) }\end{array}$ & 36.451 & 1 & 36.451 & .734 & .393 \\
\hline $\begin{array}{c}\text { Performance } \\
\text { Groups (P) }\end{array}$ & 32843.768 & 3 & 10947.923 & 220.453 & .000 \\
\hline $\begin{array}{c}\text { T x P } \\
\text { Groups }\end{array}$ & 172.913 & 3 & 57.638 & 1.161 & .326 \\
\hline Error & 8541.708 & 172 & 49.661 & - & - \\
\hline Total & 890400.000 & 180 & - & - & - \\
\hline \hline
\end{tabular}


Table 5 shows the results of the second LAT (problem-based exam). Figure 4 shows graphically the results in Table 3 (left) and Table 5 (right). Unlike the results of the first LAT (theorybased exam), the experimental groups (those who used the DT) demonstrated higher learning achievement than the control groups (those who used PT). That is, significant differences were observed between the DT and PT usage groups. The results of the independent $t$-test also highlighted a significant difference in learning achievement between the two treatment groups $(t=-2.027, p=0.044, p<0.05)$. Similarly, the ANOVA results demonstrated a significant difference between the treatment and performance groups, as shown in Table 6 ( $p=$ 0.008 and $p=0.000, p<0.05$ ). In particular, the average scores of the lower-level student groups (i.e., performance groups 1 and 2) were higher than those of the corresponding PT usage groups. A possible explanation for this is that the teacher can guide and monitor the students according to each student's individual level of understanding through the PBL process using the DT, with special attention to the lower-level students. This may also be due to the support provided by various learning materials and references, in addition to the various interactive features of the DT. Thus, the proposed PBL DT not only motivated students (especially lower-level ones) but also helped them to develop problem-solving skills and abilities, resulting in improved learning achievement. Hence, our proposed system positively influences students and results in better educational effectiveness.

Table 5. Mean percentile scores of the treatment and performance groups for the second LAT (problem-based exam)

\begin{tabular}{|c|c|c|c|}
\hline Treatment group & \begin{tabular}{|c|} 
Experimental \\
Group (DT)
\end{tabular} & $\begin{array}{c}\text { Control } \\
\text { Group (PT) }\end{array}$ & Total \\
\hline Performance group & $\begin{array}{c}\text { Average(SD) } \\
\text { Number }\end{array}$ & $\begin{array}{c}\text { Average(SD) } \\
\text { Number }\end{array}$ & $\begin{array}{c}\text { Average(SD) } \\
\text { Number }\end{array}$ \\
\hline $\begin{array}{c}\text { Group 1 } \\
(0 \sim 24.9 \%)\end{array}$ & $\begin{array}{c}72.57(11.88) \\
n=23\end{array}$ & $\begin{array}{c}65.61(9.60) \\
n=23\end{array}$ & $\begin{array}{c}69.04(11.26) \\
n=46\end{array}$ \\
\hline $\begin{array}{c}\text { Group 2 } \\
(25 \sim 49.9 \%)\end{array}$ & $\begin{array}{c}75.26(9.63) \\
n=22\end{array}$ & $\begin{array}{c}69.93(6.93) \\
n=20\end{array}$ & $\begin{array}{c}72.72(8.78) \\
n=42\end{array}$ \\
\hline $\begin{array}{c}\text { Group } 3 \\
(50 \sim 74.9 \%)\end{array}$ & $\begin{array}{c}80.99(10.34) \\
n=23\end{array}$ & $\begin{array}{c}79.52(5.93) \\
n=25\end{array}$ & $\begin{array}{c}80.22(8.28) \\
n=48\end{array}$ \\
\hline $\begin{array}{c}\text { Group } 4 \\
(75 \sim 100 \%)\end{array}$ & $\begin{array}{c}85.85(4.64) \\
\mathrm{n}=22\end{array}$ & $\begin{array}{c}85.93(6.48) \\
n=22\end{array}$ & $\begin{array}{c}85.89(5.57) \\
\mathrm{n}=44\end{array}$ \\
\hline Total & $\begin{array}{c}78.63(10.72) \\
n=90\end{array}$ & $\begin{array}{c}75.37(10.80) \\
n=90\end{array}$ & $\begin{array}{c}77.00(5.57) \\
n=180\end{array}$ \\
\hline
\end{tabular}

Table 6. Analysis of variance for problem-based exam

\begin{tabular}{|c|r|r|r|r|c|}
\hline Variance & \multicolumn{1}{c|}{$\begin{array}{c}\text { Sum of } \\
\text { Squares }\end{array}$} & $\begin{array}{c}\text { Degree } \\
\text { of } \\
\text { Freedom }\end{array}$ & $\begin{array}{c}\text { Mean } \\
\text { Squares }\end{array}$ & F & p-value \\
\hline $\begin{array}{c}\text { Treatment } \\
\text { Groups (T) }\end{array}$ & 532.911 & 1 & 36.451 & .734 & .393 \\
\hline $\begin{array}{c}\text { Performance } \\
\text { Groups (P) }\end{array}$ & 7714.729 & 3 & 10947.923 & 220.453 & .000 \\
\hline $\begin{array}{c}\text { T x P } \\
\text { Groups }\end{array}$ & 370.709 & 3 & 57.638 & 1.161 & .326 \\
\hline Error & 12529.202 & 172 & 49.661 & - & - \\
\hline Total & 1088292.750 & 180 & - & - & - \\
\hline \hline
\end{tabular}
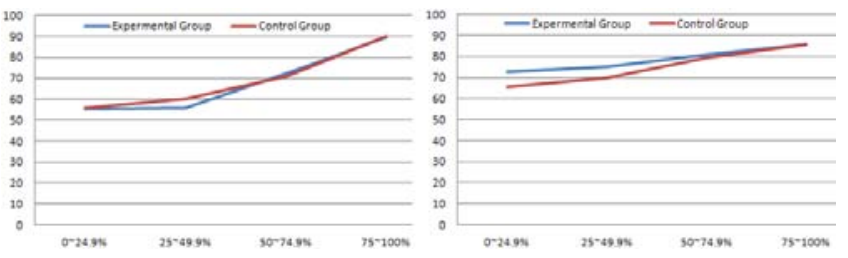

Fig. 4. Results for learning achievement in the first (left) and second (right) LATs

\section{CONCLUSION}

We developed a PBL DT for a general computing course given at a high school in South Korea. The main focus of the DT was to support self-directed and differentiated learning to enhance overall learning achievement. For the experiment, the DT was used in an actual classroom, and two LATs were administered after conducting the PBL lessons using the DT for a certain period to verify the DT's educational effectiveness. The first LAT was a theoretical knowledge exam and the second LAT was a problem-based practical exam. The scores of the final exam that took place right before using the DT were used for a comparison of learning achievement.

The DT students acquired the theoretical knowledge of the subject as well as the PT class students, even though the DT was centered on problem sets. However, in the problem-based practical exam, DT students, especially lower-level students, performed slightly better than corresponding PT students. That is, the students in the DT classes improved their problemsolving abilities and demonstrated a better practical understanding of the subject than those in the PT classes.

Finally, feedback about the system was generally positive and the overall level of user satisfaction was high (average: 78), although there were some suggestions for improvements such as increasing search performance and enhancing note-taking features. Future studies should investigate learning parameters that may influence the effectiveness of learning via the proposed PBL DT through a wider range of practical case studies.

\section{ACKNOWLEDGEMENT}

This work was supported by the research grant of the Chungbuk National University in 2011.

\section{REFERENCES}

[1] Lim, C., Noh, K., Song, H., Jang, S., Choi, S., Nam, Y., Lee. K. "Science Digital Textbook 2.0 Model and Development Methodology," Korean Education \& Research Information Service (KERIS), Research Report CR 2011-2, Republic of Korea, 2011.

[2] Ministry of Science, Education and Technology "Road to an Advanced Country: Smart Educational Strategy Action Plan,” Republic of Korea http://www.mest.go.kr/web/1127/ko/ board/view.do?bbsId=192\&mode=view\&boardSeq $=2573$ 


\section{4, 2011.}

[3] Ministry of Science, Education and Technology "Strategy for Commercial Use of Digital Textbook," http://www.nhrd.net/nhrdapp/jsp/tre0202.jsp?sSeq=2007 0255(2007) http://en.wikipedia.org/wiki/Digital_Textbook (2009)

[4] Korean Education \& Research Information Service "Digital Textbook," $\underline{\text { http://www.dtbook.kr/renew/english/index.htm, }}$ Feb., 2009.

[5] Park, C. S., Kim, M., Yoo, K. H. "Design and Implementation of a Problem-based Digital Textbook," Manuscript, 2012.

[6] Park, C. S. Project-based learning method employing digital textbook, Master thesis, Graduate School of Education, Chungbuk National University, South Korea, 2011.

[7] Ku, K. M. Study on the Improvement of Computer Knowledge and Practical Skills by Applying Task-Based Learning, Master Thesis”, Graduate School of Education, Gyeongin National University of Education, South Korea, 2003.

[8] Barr, R. J.,Tagg, J. “From Teaching to Learning: A New Paradigm for Understanding Education,” Change, Vol. 27, No. 6, pp.12-25, 1995.

[9] Hmelo-Silver, C. E. "Problem-based learning: What and How Do Students Learn?”, Educational Psychology Review, Vol. 16, No. 3, pp. 235-266, 2004

[10] Barrow, H. S. "A taxonomy of problem-based learning methods,” Medical Education, Vol. 20, pp.481-486, 1986

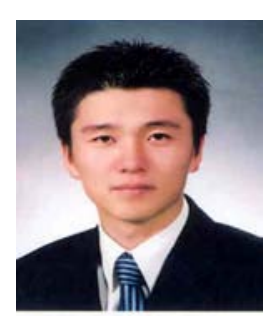

\section{Chan-Seok Park}

He is a teacher who is working for a high school, Korea. He received the M.S. in information computer division from Chungbuk National University in 2011. His research interests include u-Learning systems, computer graphics, digital textbook.

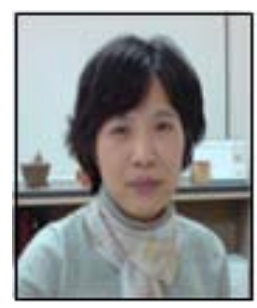

\section{Mihye Kim}

She received her Ph.D. in Computer Science and Engineering in 2003, from New South Wales University, Sydney, Australia. She is currently an Associate Professor in the Computer Science Education Department at Catholic University of Daegu, South Korea. Her research interests include knowledge management and retrieval, computer science education, e-learning, and digital textbooks.

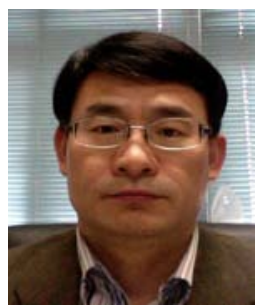

\section{Kwan-Hee Yoo}

He is a professor who is working for department of Computer Education and department of IIE(information industrial engineering) at Chungbuk National University, Korea. He received the B.S. in Computer Science from Chonbuk National University, Korea in 1985, and also received M.S., Ph.D. in computer science from KAIST (Korea Advanced Institute of Science and Technology), Korea in 1988 and 1995, respectively. His research interests include uLearning systems, computer graphics, 3D character animation, dental/medical applications. 